\title{
How Literature Circles Support EFL College Students' Literary and Literacy Learning in a Children's and Adolescent Literature Course
}

\author{
Yi-Ching Su, Kun Huei Wu \\ Department of English \\ Aletheia University, Taiwan
}

\begin{abstract}
This article describes what literature circles are, how they are applied in an EFL college level children's and adolescent literature course, and how they support the students' literary and literacy learning. On reading English texts, many college students in Taiwan have been driven by external incentives such as tests and grades, and most of them lack motivation to read English texts. They have little choice or ownership of their reading, and they write formal book reports or take multiple-choice tests after reading an English novel. Because of this type of reading education, the students are not accustomed to creating their own meaning of the text, and they are not used to read English texts for enjoyment. To create a low-risk environment for the EFL college students to practice reading and discussing English literary works, the researchers applied literature circles in the children's and adolescent literature course. The results show that literature circles motivate the EFL college students to conduct independent reading, and they support the students' literary and literacy learning.
\end{abstract}

\section{Introduction}

Literature circles are a form of literary engagement in which students meet in small groups to discuss and respond to a book that they are all reading. In literature circles, each member agrees to take specific responsibilities during discussion sessions. Literature circles meet regularly, and the discussion roles change at each meeting [1]. In literature circles, the students' inquires and thoughts drive the discussion.

In literature circles, the students discuss their understandings and personal and literary connections to what they read. Literature circles support students to become skillful readers who take ownership of their reading and construct meaning in an active way. They also break the typical classroom discourse pattern in which students respond only to teachers' questions, and they allow students to take responsibility for developing their own questions and discussing their interpretations for texts, just like "real" readers [2]. Plenty of research has investigated the effects of incorporating literature circles in elementary language arts classrooms, especially in the teaching of first language. However, little research has been published on the use of literature circles with ESL or EFL college level learners [3].
The present study aims to investigate how the EFL college students participate in literature circles in a children's and adolescent literature course, and how literature circles support the students' literary and literacy learning.

\section{Theoretical Framework}

This study is based on the following theories: reader response theory and sociocultural theory. This section explains what the two theories are, and how they are related to this study.

\subsection{Reader response theory}

Reader response theory stresses the importance of a reader's role in interpreting a text. It views reading as a transaction, "a two-way process involving a reader and a text at a particular time and under particular circumstances" [4], and it rejects the notion that there is one single or fixed meaning inherent in text. According to Rosenblatt [4], reading falls somewhere on the continuum between the aesthetic and the efferent stances. When a reader is engaged in aesthetic reading, "the reader's primary concern is with what happens during the actual reading event" [4] - the thoughts, feelings, and sensations that one experiences in the moment. Efferent reading, on the other hand, focuses the reader's attention primarily on what can be carried away from the reading event. Rosenblatt argues that aesthetic evocation of texts should be primary and that analysis, which involves efferent reading, should follow later. Literature circles invite students to formulate questions, make connections, and highlight passages that they find meaningful. It engages students in both aesthetic and efferent reading.

\subsection{Sociocultural theory}

Sociocultural theory of human learning views learning as a social and an interactive process that is specific to the learner's sociocultural environment. In the development of cognition, social interaction plays a fundamental role. Vygotsky [5] believed everything is learned on two levels. The first is through interaction with others, and the second is through collaboration with more capable peers or under adult guidance. The implementation of literature circles as a literary engagement in a 
literature course reflects Vygotsky's sociocultural theory [6], [3]. In literature circles, each student brings in personal responses and individual interpretations. When students talk about their responses and listen to each other's various perspectives, they are engaged in an interpretive community, in which different students' perspectives on a text have a profound effect on their experience of the text [6]. When students come together in each literature circle to discuss the book they have chosen, they move from individually creating meaning to socially negotiating that meaning with their group members. When students are engaged in literature circles, they discuss questions, share responses, and explore interpretations. They reflect, revise meaning, and they extend their views [7].

\section{Literature review}

From the implementation of literature circles, students are provided with opportunities to read independently, to make personal connections, to question their puzzles, and to discuss multiple interpretations. Among the various literary engagements, literature circles have been viewed as a durable and sustainable one in many language arts and ESL/ EFL classrooms.

Lin [8] stated that "stronger reader-text relationships, improved classroom climate, enhanced degrees of gender equity and understanding, and a learning environment more conductive to the need and abilities of English language learners" [8] were the results of the implementation of literature circles. The study done by Peralta-Nash and Dutch [9] showed that literature circles provided a low-risk learning environment for ESL students. The studentled literature circles helped the ESL students who were reluctant to respond in a whole group setting due to the limited English ability and the fear of being wrong in front of the whole class to take risks and feel comfortable participating in a small group discussion. The study also pointed out that the ESL students were able to make text-to-life connections and have in-depth discussion on the text. The study conducted by Marine-Roldan and Lopez-Robertson [10] also showed that even bilingual first graders were able to clearly articulate their thoughts about the text they chose to read and make connections between the text and their life experiences. Kim's [11] discourse study showed that when L2 students were engaged in literature circles, they had pleasant reading experiences and enhanced communicative competency. The findings of Lin's [12] study about the effects of literature circles on $25 \mathrm{EFL}$ fifth graders revealed that through literature circles, the students made improvement in the reading comprehension. The students also had positive attitudes toward reading the books. Chou [13] studied EFL high school students' talk in response to short stories in literature circles. The result showed that the students made connections between the stories and their lives. They were engaged in sharing and discussing their responses and thoughts, and they worked collaboratively to construct meaning.

The reviewed studies about the implementation of literature circles in ESL/EFL classrooms revealed the benefits of literature circles, such as improved comprehension skills, increased student participation in a low-risk environment, enhanced motivation in reading, expanded collaborative discussion, and enriched reader and text relationship. This present study will investigate how the EFL college students participate in literature circles in a children's and adolescent literature course, and how literature circles support the students' literary and literacy learning.

\section{Methodology}

To investigate how literature circles support the EFL college students' literary and literacy learning, the researchers conduct a qualitative case study.

\subsection{Qualitative research}

To study how literature circles support EFL college students' literary and literacy learning in a children's and adolescent literature course, the researchers chose to conduct qualitative case study research. On the focus and concern of qualitative research, Merriam [14] suggested that qualitative study focuses on "process, meaning, and understanding" [14], and its key concern is "understanding the phenomenon of interest from the participants' perspectives" [14]. The nature of qualitative study allows the researchers to achieve the research goal and to understand how literature circles support the EFL college students' literary and literacy learning.

\subsection{Case studies}

Among different types of qualitative research, the researchers chose to conduct a descriptive case study. On conducting case study research, Stake [15] stated that we expect to "catch the complexity of a single case" [15] and aim to "thoroughly understand the case" [15]. A case study design is chosen purposefully because "researchers are interested in insight, discovery, and interpretation rather than hypothesis testing" [14]. Having a sincere interest in understanding how literature circles support the EFL college students' literary and literacy learning, the researchers purposefully employed a case study design to study the complexity of the literary and literacy learning process with the support of literature circles. 
According to Merriam [14], descriptive case studies in education are useful in "presenting basic information about areas of education where little research has been conducted. Innovative programs and practices are often the focus of descriptive case studies in education" [14]. Merriam [14] also argued that, "Case study has proven particularly useful for studying educational innovations, for evaluating programs, and for informing policy" [14]. There is a lack of research examining how literature circles support EFL college students' literary and literacy learning. To inform educators the role of literature circles in EFL college students' literary and literacy learning, the researchers chose to conduct a descriptive case study to provide a rich description of the implementation of literature circles in the EFL college students' children's and adolescent literature course.

\subsection{Research participants}

Ten EFL college students who took the researchers' children's and adolescent literature course were chosen as the research participants. All of them were English-majored sophomores. The researchers selected the ten participants because they participated actively in the literature circles.

\subsection{Research context}

This study was conducted in a university located in the northern part of Taiwan. The children's and adolescent literature course was a selective course offered by the English department every other semester. It met once a week for two hours. In the first hour, the class discussed issues about children's and adolescent literature in education, reviewed and interpreted literary works for children and adolescent in various genres. In the second hour, the students were divided into groups of 5 and participated in literature circles and literature-related activities. In literature circles, each group member takes on one of the following discussion roles: discussion director, summarizer, literary luminary, illustrator, and connector. The students take turns to take on different roles every meeting. Acting as a facilitator in the group, a discussion director develops openended questions related to the sections being read and facilitates group discussion. A summarizer provides a summary that describes what has happened in the sections being read. A literary luminary selects significant passages from the reading, determines why they are important, calls other group members' attention to the passages, and leads discussion about them. The selections can focus on that which is interesting, powerful, puzzling, controversial, or thought-provoking. An illustrator draws some kind of picture (a sketch, cartoon, diagram, flow chart or stick-figure scene) related to the sections being read. A connector sees relationships between the reading and the real world: students' personal lives, people their age, the happenings at school or in their community and the world, or other literary works that they have read previously [1].

\subsection{Data source}

Data sources include the literature circles role sheets from the participants, the audiotapes documenting interviews with the participants, and the field notes and reflection journal from the researcher.

\subsection{Data analysis}

To analyze the research data, the researchers coded the research data first. Based on the literary elements (e.g., theme, symbolism, characterization, point of view), the researchers developed a list of preliminary codes, found patterns and themes, and then conducted "analytic coding" [16]. The researchers followed the constant comparative method [17] to analyze the data in order to find emerging themes, patterns, and categories [18]. Triangulation [16] and member checking [15] were also used to provide research validity.

\section{Results}

The purpose for implementing literature circles in the children's and adolescent literature course is to provide opportunities for the students to share and discuss their thoughts of the English literary works with their peers and learn to be competent readers of literature. Literature circles allow the students to "practice and develop the skills and strategies of good readers" [19], since the role sheets break down the skills of a mature reader into manageable parts so that every group member is able to take turns to practice one aspect of what a mature reader does naturally. Literature circles give structure to discussions about literature, and they offer a nonthreatening and community-like setting for the students to learn and interact with one another. The collaborative and dialogic nature of literature circles also invite the students to share feelings, opinions, experiences, and responses to the literary works with their group members [10]. This study aims to investigate how the EFL college students participate in literature circles, and how literature circles support the students' literary and literacy learning. The following sections explain what the students do in literature circles and how different roles in literature circles support the students' literary and literacy learning. 


\subsection{Discussion director}

A director is responsible for guiding the literature circle through the discussion of the sections being read. To engage the group members in the discussion, the discussion director poses open-ended questions to invite the group members to share their responses to the readings and discuss their thoughts and interpretations of the text with others. For example, while reading Helen Frost's Keesha's House - a story about a group of struggling teenagers trying to find a safe place to call home - Tina, the discussion director asked, "What would a real home be like to you?". In the last literature circle while reading Kate DiCamillo's The Miraculous Journey of Edward Tulane, a story about an arrogant China rabbit learned to love through a life-changing journey, Jill invited her group members to imagine if they were Edward the rabbit, what they would say to the owner, Abilene, after a long journey away from home and finally reunite with his mistress. While leading the group discussion, the discussion director practices higher level thinking skills, such as creating thought-provoking questions, responding to group members' ideas and opinions, and asking follow-up questions. At the same time, the group members articulate their opinions, predict what will happen in the story, and listen to other members' interpretations. In the literature circles, the discussion director and the group members articulate their perspectives, make predictions, step into the characters' shoes, discuss various interpretations, and reinterpret their understandings of the text.

\subsection{Summarizer}

Being a summarizer, the student needs to retell the story in his own words and choose the important points to present in his summary. Acting as a summarizer, the student reads the story numerous times in order to see the overall picture of the work, to know the plot and sequence of the story, to be familiar with the story language, and to extract important events and details in the story.

\subsection{Literary luminary}

A literary luminary is responsible for bringing the group members' attention to key passages, lines, quotes, or details from the text. In order to find and document key passages, the literary luminary makes a very close reading of the text. He pays close attention to well-written or key passages in the text, and he looks carefully for literary devices, such as figurative language, metaphor, and wordplay. For example, while discussing Katherine Applegate's Home of the Brave, a story describing an African immigrant boy's journey from hardship to hope, Tim, a literary luminary, read aloud two lines from the story in the literature circle. The first one is, "I open my eyes and gaze out the round window." Tim shared this line with the group members because he thought it implies that Kek, an African boy whose father and brother died in war and mother missing, is looking for hope when he is alone on the plane to America. The second line Tim read aloud is, "It's a strange pain to be with those you belong to and feel you don't belong." Tim shared this thoughtprovoking line with his group members and invited them to talk about whether they have the similar feeling in their life experiences. Reading and hearing books with rich examples of language is one of the best ways for students to gain appreciation for language and expand their vocabulary knowledge [6]. In the literature circle, Tim not only read aloud the lines he selected, but also dramatized the character's words, actions, and thoughts through vocal expression of his interpretation of Kek's personality. It helps Tim develop interpretive expression, and it engages the group members in savoring the sounds and imagery of the words. In literature circles, the literary luminary dramatizes the passages, explains why he chose certain passages, and he invites the group members to discuss what they think the passages mean and their thoughts about the passages. The literary luminary and the group members all exercise responding to the text in an analytical way.

\subsection{Connector}

The responsibility of a connector is to see relationships between the reading and the real world. The connector makes connections between elements in the reading to his life experiences and values, to other texts read previously, and to the events from around the world. In literature circles, the connector serves as a facilitator of reader-text transaction. He helps the group members to make connections between themselves and the text and develop intertextual insights [6]. While discussing Kate DiCamillo's The Miraculous Journey of Edward Tulane, Sarah, the connector, said "When Edward went overboard and sank into the ocean, he felt helpless and afraid. When I feel blue and get really depressed, I have the same feeling and think that I'm going to be drowned in the sea of depression." Sarah's words stroke a chord with her group members. They talked about Edward's situations and feelings, and they shared their personal experiences and how they dealt with depression. In addition to making text-to-self connections, the students also make text-to-text connections. While discussing a chapter from Yann Martel's Life of Pi, Laura, a connector, pointed out that the story reminds her of Daniel Defoe's Robinson Crusoe. Making text-totext connections help the group members understand and predict what might happen in the text they are 
reading currently. It also supports them to gain new insights about the texts they read before. When the group members are engaged in transacting with the text, they step into the protagonist's position. It supports the members to develop the empathy toward the characters and to experience another life. Through sharing and discussing the connections made with the text, the connector and the group members exercise responding to the text in an associative way and come to in-depth understanding of the text.

\subsection{Illustrator}

In literature circles, an illustrator draws some kind of picture, such as a sketch, a cartoon, a diagram, a flow chart, or a stick-figure scene related to the reading. After the illustrator finishes the drawing, the group members study the picture and guess the meaning of it. Then, the illustrator explains the story behind the picture and why he drew the picture in a certain way. When the illustrator responds to the reading through drawing a picture, he creates mental images of descriptions of characters, settings, and the plot, which is similar to what a mature reader does. The act of translating meanings from printed words to symbols promotes thinking that goes beyond reiteration of received ideas. Making symbolic reactions to the text and interpret symbolic responses support the students to understand the story structure, the meaning of the story, the relationships between the characters, and the development of the plot.

\section{Conclusions}

Literature circles provide the EFL students with a safe and low-risk setting to engage in meaningful and student-directed dialogue about books they read. In the community formed by readers, the students feel comfortable talking about books, sharing their life experiences, expressing their points of view, negotiating meaning and seeking clarification. In literature circles, the students experience dynamic interaction among readers and texts, and they do everything that mature readers do: choose a book, assemble members, plan a reading and meeting schedule, decide each member's role in every meeting, establish meeting rules, keep a reading record, and sustain on-task conversations. During the whole process, the EFL students actively use authentic language for real purposes, which support their literary and literacy learning. While serving different discussion roles in literature circles, the students make predictions, visualize characters and settings, use literary knowledge to evaluate and interpret texts, discover multiple perspectives, make literary interconnections, and develop intertextual insights. The students' literary experiences with texts are enriched by their place within the context of literature as a whole.

Collaborative discussion with peers plays an important role in reinforcing comprehension skills when students learn a new language [20]. As the students record responses in journals, ask questions, express opinions, respond to others, elaborate on the dialogue, complete discussion role sheets, justify interpretations, reread the text, negotiate meaning with peers, and build shared meanings in literature circles, they develop communicative competence, deepen reading comprehension, foster critical thinking ability, and improve language and literacy skills, which are essential for helping EFL students to grow as independent readers.

To participate in literature circles, the students are motivated to read outside the class; to document their feelings, thoughts, and responses while reading; and to ask questions about the readings to figure out what the text really means. Shifting the teaching and learning responsibility from teachers to students, literature circles nurture the pleasure of reading literature and literacy skills simultaneously, and they support the readers to develop a lifelong love for reading and consciousness about themselves as readers.

\section{References}

[1] Daniels, H. (1994). Literature circles: Voice and choice in the student0centered classroom. Portland, ME: Stenhouse.

[2] Brabham, E.G. \& Villaume, S.K. (2000). Continuing conversations about literature circles. The Reading Teacher, 54(3), 278-280.

[3] Morales, A. S. \& Carroll, K. (2015). Using literature circles in the ESL college classroom: A lesson from Puerto Rico. Columbian Applied Linguistics Journal, 17(2), 193206.

[4] Rosenblatt, L. (1982). The literary transaction: Evocation and response. Theory into Practice, 21(4), 268277.

[5] Vygotsky, L.S. (1978). Mind in society: Development of higher psychological processes. Cambridge, MA: Harvard University Press.

[6] Lehman, B. (2007). Children's literature and learning. New York: NY: Teachers College Press.

[7] Medina, C. (2007). Literature circles: a door to students' life experiences in the classroom. Columbian Applied Linguistics Journal, 9, 247-261.

[8] Lin, C. (2004). Literature circles. Teacher Librarian, 31(3), 23-25. 
[9] Peralta-Nash, C., \& Dutch, J.A. (2000). Literature circles: Creating an environment for choice. Primary Voices K-6, 8(4), 444-450.

[10] Martinez-Roldan C. M. \& Lopez-Robertson, J.M. (2000). Initiating literature circles in a first-grade bilingual classroom. The Reading Teacher, 53(4), 270-281.

[11] Kim, M. (2004). Literature discussions in adult L2 learning. Language and Education, 18(2), 145-166.

[12] Lin, S. (2006). The effects of literature circles on EFL learning of children in a bilingual class. Unpublished master's thesis. Kaohsiung Normal University, Kaohsiung.

[13] Chou, L. (2007). Exploring student talk in a Taiwanese English reading class. Journal of Educational Research and Development, 3(2), 137-162.

[14] Merriam, S.B. (1998). Qualitative research and case study applications in education. San Francisco, CA: Jossey-Bass.

[15] Stake, R.E. (1995). The art of case study. Thousand Oaks, CA: SAGE.

[16] Glesne, C. (1999). Becoming qualitative researchers: An introduction. New York: Longman.

[17] Goetz, J.P. \& LeCompte, M.D. (1984). Ethnography and qualitative design in educational research. Orlando, FL: Academic Press.

[18] Patton, M.Q. (2002). Qualitative research and evaluation methods. Thousand Oaks, CA: Sage.

[19] DaLie, S.O. (2001). Students becoming real readers: Literature circles in high school English classes. In B. Ericson (Ed.), Teaching Reading in High School English Classes. (pp. 84-100). Urbana, IL: National Council of Teachers of English.

[20] Ketch, A. (2005). Conversation: The comprehension connection. The Reading Teacher, 59(1), 8-13. 